\title{
Interactive comment on "Atmospheric new particle formation in China" by Biwu Chu et al.
}

\section{Anonymous Referee \#2}

Received and published: 30 October 2018

The authors summarized the data of NPF measurements reported in China in the past 14 years. The features of NPF parameters such as frequency, FR and GR were described, and the possible reasons behind them were also discussed. The author raised attention on the ambiguous relationship between NPF and haze formation, and pointed out the importance of comprehensive study including laboratory works and field measurement on NPF research in China. The data set of this paper is full accurate, could be helpful for other researchers. However, there are still some concerns to be satisfied before I suggest the paper could be published on ACP.

Major suggestions: In Section 3, the authors made so far most complete and detailed summary of NPF field measurement results in China. However, on scope of scientific issues, similar understandings were already raised by the review papers from Wang et al, Kulmala et al and Kerminen et al. The authors should strengthen the highlight of this paper by: 
1. Emphasizing the new findings from studies published in recent years, utilizing the up-to-date techniques, e.g. measurements of sub-3 $\mathrm{nm}$ particles and sulfuric acid, since these were not included in former papers.

2. Enriching the discussion in relationship between haze and NPF in Section 4, concentrating on issues such as : 1) threshold of the occurrence of NPF; 2) contribution of NPF on haze formation, in comparison with primary emissions.

Minor suggestions:

1. Page2 Line 25 "recentZu years" Type error.

2. Page3 Line 26 The air pollution level decreases from NCP to PRD, or from north to south, among these three regions. References are needed.

3. Page5 About regional occurrence of NPF, Shen et al's work is encouraged to be cited.

Shen, X. J., Sun, J. Y., Kivekas, N., Kristensson, A., Zhang, X. Y., Zhang, Y. M., Zhang, L., Fan, R. X., Qi, X. F., Ma, Q. L., and Zhou, H. G.: Spatial distribution and occurrence probability of regional new particle formation events in eastern China, Atmospheric Chemistry And Physics, 18, 587-599, 10.5194/acp-18-587-2018, 2018.

4. Page6 Season and the origin of air mass make impact on occurrence of NPF by influencing the level of CS and precursors. The suggestion is moving the discussions on them after those on CS and gaseous pollutants.

5. Page7 CS/GR may not be a good index on the probability of NPF, because GR couldn't represent the level of nucleation precursor. The compounds that are crucial for nucleation (e.g. H2SO4, amine) may be negligible in particle growth. The suggestion is providing a review the value of SO2*UVB/CS in references, since the measurement of $\mathrm{H} 2 \mathrm{SO} 4$ was quite limited in China.

Kerminen, V. M., Chen, X. M., Vakkari, V., Petaja, T., Kulmala, M., and Bianchi, F.: 
Atmospheric new particle formation and growth: review of field observations, Environ. Res. Lett., 13, 38, 10.1088/1748-9326/aadf3c, 2018.

Kulmala, M., Kerminen, V. M., Petaja, T., Ding, A. J., and Wang, L.: Atmospheric gas-to-particle conversion: why NPF events are observed in megacities?, Faraday Discussions, 200, 271-288, 10.1039/c6fd00257a, 2017.

Wang, Z., Wu, Z., Yue, D., Shang, D., Guo, S., Sun, J., Ding, A., Wang, L., Jiang, J., Guo, H., Gao, J., Cheung, H. C., Morawska, L., Keywood, M., and Hu, M.: New particle formation in China: Current knowledge and further directions, The Science of the total environment, 577, 258-266, 10.1016/j.scitotenv.2016.10.177, 2017.

Interactive comment on Atmos. Chem. Phys. Discuss., https://doi.org/10.5194/acp-2018-612, 2018. 